\title{
De rol van de sociale omgeving bij gezond oud worden
}

\author{
PAUL VAN DE VIJVER \& DAVID VAN BODEGOM
}

In tegenstelling tot wat veel mensen denken, worden ouderdomsziektes niet alleen door ouderdom maar vooral door leefstijl veroorzaakt. Steeds meer studies laten zien dat de omgeving een grote invloed heeft op de leefstijl van mensen. Naast de fysieke omgeving speelt bij mensen de sociale omgeving een belangrijke rol, waardoor ingrijpen in die sociale omgeving de kans biedt om gezond oud worden te stimuleren.

\section{Effect van de omgeving op leeftijd}

In Nederland komen overgewicht, hoge bloeddruk, hoog cholesterol en suikerziekte veel voor bij ouderen. Het is een greep uit de groep ouderdomskwalen die door de meeste mensen worden gezien als normale veroudering. Veroudering komt immers met gebreken. Ons onderzoek in Ghana laat echter zien dat mensen ook oud kunnen worden zonder die gebreken. Daar komen hart en vaatziektes en suikerziekte nauwelijks voor. Dit komt door de omgeving in Ghana, waar mensen tot hoge leeftijd op het land moeten werken om in hun dagelijkse voedselbehoefte te voorzien. De omgeving in Ghana lijkt meer op de omgeving van schaarste, waarin wij tot voor kort duizenden jaren hebben geleefd. Ons lichaam is afgesteld om zo veel mogelijk energie tot ons te nemen en zo weinig mogelijk te verbruiken. Deze 'lichaamsinstelling' leidt in de huidige omgeving met een overaanbod aan voedsel en weinig noodzaak tot beweging tot het metabool syndroom: overgewicht, hoog cholesterol, hoge bloeddruk en te hoge bloedsuikers. Er wordt door overheid en artsen geprobeerd om dit te- gen te gaan door verboden en geboden, maar adviezen over dieet en meer beweging werken niet tot nauwelijks. Wij denken vaak dat we bewust kiezen wat en hoeveel we eten en hoeveel we bewegen. Maar die keuzes worden sterk door de omgeving beïnvloed.

In de supermarkten liggen de chocoladerepen in het volle zicht bij de kassa voor een laatste impulsaankoop en betalen frisdrankproducenten om hun producten op ooghoogte in de schappen te hebben, opdat ze meer verkocht worden. Onze omgeving stimuleert inactiviteit; in warenhuizen, kantoorpanden en zelfs ziekenhuizen is de roltrap of lift prominent in beeld en dicht bij de ingang en is de trap verstopt achterin het gebouw. Ook de omgeving thuis stimuleert overconsumptie. Het servies is steeds groter geworden, met als gevolg dat onbewust onze porties ook in grootte zijn toegenomen. Mensen eten geen bewust gekozen hoeveelheid voedsel, maar eten tot het bord leeg is. In een experiment waarbij een soepkom van onder ongezien kon worden bijgevuld, bleken proefpersonen niet in de gaten te hebben dat ze gemiddeld $73 \%$ 
meer soep aten. De mensen die uit de bijgevulde soepkom aten, voelden zich achteraf net zo voldaan als de groep die uit een normale soepkom had gegeten. De huidige omgeving is er niet een van schaarste, maar van overvloed. Er is in feite een mismatch ontstaan tussen onze genen en omgeving. Aangezien wij onze genen niet kunnen veranderen, zullen wij de omgeving moeten veranderen.

Verleiden tot beter eten en meer bewegen is in verschillende omgevingen mogelijk. In de publieke ruimtes zou de trap de logische keuze kunnen zijn en de lift of roltrap meer uit het zicht geplaatst kunnen worden. Op kantoor kan een werkgever voor zijn werknemers een zit/sta bureau aanschaffen, waarmee de werknemer niet meer genoodzaakt is om hele dagen zittend zijn werk te doen. Als een vergaderkamer wordt ingericht met alleen een hoog bureau en zonder stoelen, zal er vaker staand vergaderd worden. Er wordt dan niet alleen meer energie verbruikt, maar ook efficienter vergaderd. Staande vergaderingen duren slechts twee derde van de tijd van zittende vergaderingen, zo blijkt uit onderzoek. Thuis kunnen de mensen ervoor kiezen om tijdens het eten de pan niet op tafel te zetten, maar in de keuken op te scheppen. Als de pan op tafel staat eten we namelijk meer. De aanschaf van kleiner servies zorgt ook voor minder voedsel inname. Een meta-analyse van 72 studies uit 20 I 5 toont aan dat het gebruik van kleiner servies, kleinere porties of een kleinere verpakking leidt tot minder voedselconsumptie (Hollands et al., 20 I 5). Verder kan een herindeling van de koelkast helpen om bijvoorbeeld meer groente te eten. In plaats van de groente te verstoppen in de groentelade, kun je die beter op ooghoogte in de koelkast leggen. Eveneens blijkt uit onderzoek dat mensen meer fruit eten als het in het zicht staat. Maar dat geldt ook voor koekjes; mensen eten meer koekjes als er een doorzichtige koektrommel in hun omgeving is dan wanneer er een niet-doorzichtige koektrommel is.

Kortom, er zijn legio voorbeelden waarin de fysieke omgeving onze gezondheidskeuzes en onze leefstijl beïnvloedt en voorbeelden van aanpassingen in de omgeving die leiden tot een gezondere leefstijl. Sommige aanpassingen kosten allicht meer moeite dan andere, maar eenmaal toegepast kun je de aanpassing haar werk laten doen. Op dat moment zorgt de omgeving voor een onbewuste en moeite-

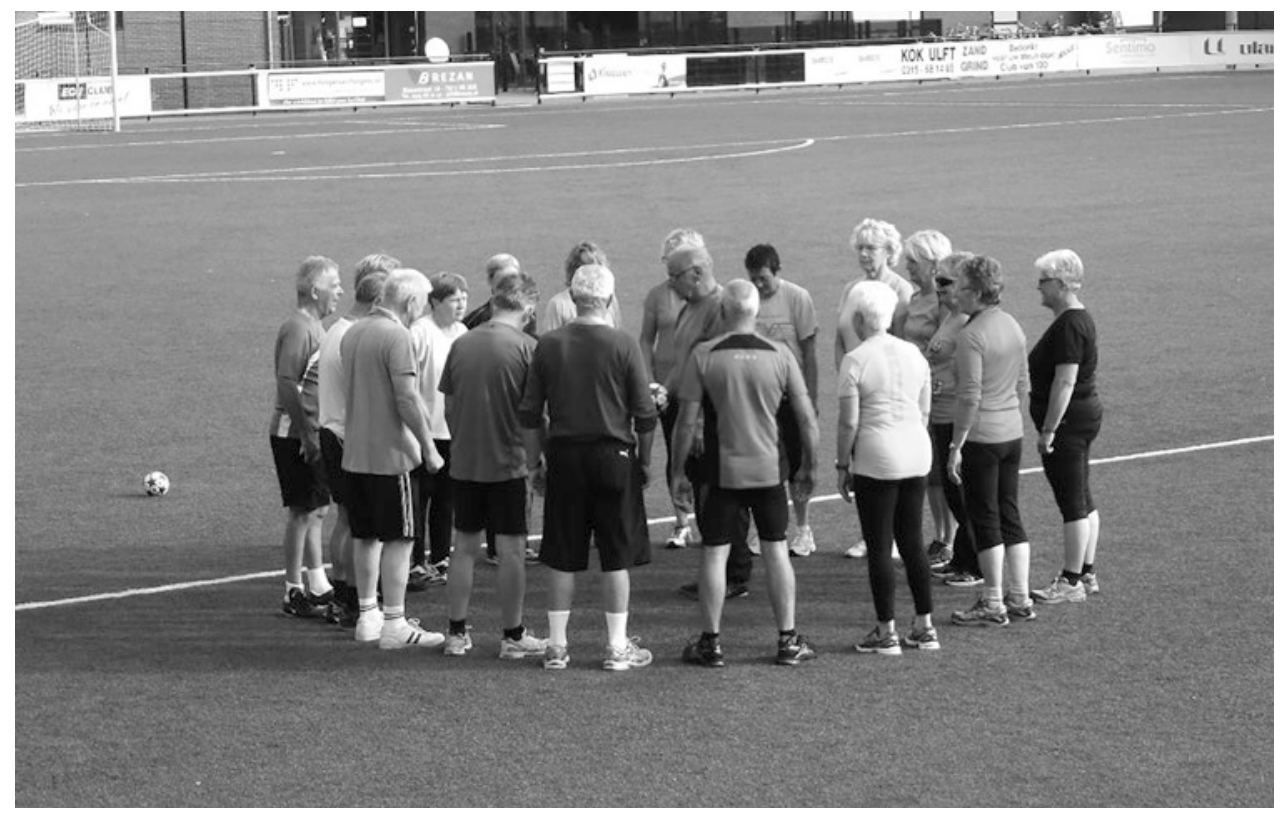

Foto: Freewheel club 
loze verandering van de leefstijl. In het boek 'Oud worden in de praktijk' pogen wij mensen bewust te maken van de belangrijke rol die de omgeving speelt bij gezond oud worden (Van Bodegom \& Westendorp, 20 I 5). In dat boek hebben we het niet alleen over de invloed van de fysieke omgeving, maar ook over de invloed van collega's, buren, vrienden en familie: de sociale omgeving.

\section{Sociale omgeving}

Aristoteles stelde al in de vierde eeuw voor Christus dat de mens van nature een sociaal wezen is, een zoön politikon, die alleen in gezelschap zijn volmaaktheid kan vinden. De sociale omgeving heeft grote invloed op onze gezondheid, ons welbevinden en de manier waarop wij verouderen. In veel studies wordt gevonden dat mensen die eenzaam zijn een verhoogde sterftekans hebben die wel $26 \%$ hoger is dan mensen die niet eenzaam zijn (Holt-Lunstad, Smith, Baker, Harris, \& Stephenson, 2015). Andersom is het zo dat mensen die gelukkig zijn een lagere sterftekans hebben. (Koopmans, Geleijnse, Zitman, \& Giltay, 2010) Ten eerste kan de sociale omgeving direct invloed uitoefenen op fysiologische en psychologische processen, vaak via stress. Onderzoek wijst uit dat hoge eisen, weinig zelfcontrole en weinig behulpzame collega's op de werkvloer de kans op hart en vaatziekten met een derde doet toenemen. Ten tweede kan de sociale omgeving de gezondheid beïnvloeden via gedrag, leefstijl. Roken is daar het beste voorbeeld van: het is één van de meest ongezonde gewoontes en heel afhankelijk van de sociale omgeving. Ook obesitas is afhankelijk van sociale omgeving. Onderzoek uit 2007 toonde aan dat obesitas 'besmettelijk' is en zich in sociale groepen als ware het een infectie verspreidt. De kans op obesitas neemt met $57 \%$ toe als je een vriend hebt die recent ook obesitas heeft ontwikkeld (Christakis \& Fowler, 2007).

Je vriendengroep heeft grote invloed op je leefstijl, bijvoorbeeld op hoeveel je eet, beweegt, of je gaat roken en of je dik wordt. Gelukkig zijn de invloeden van de sociale omgeving niet alleen negatief. Sporten is een sociale bezigheid en of je gaat sporten is ook afhankelijk van je sociale omgeving. Ik - Paul - heb dit zelf van dichtbij meegemaakt. Toen ik in Den Haag woonde, liep ik minstens drie keer per week ro $\mathrm{km}$ hard. $\mathrm{Na}$ mijn verhuizing naar Leiden en verandering van directe vriendengroep, ging ik nog zelden hardlopen. Toen ik echter een sportieve vriendin kreeg, nam mijn sportfrequentie weer toe. Zou deze positieve invloed van de sociale omgeving ook als een interventie benut kunnen worden om ouderen meer te laten bewegen?

\section{De sociale omgeving inzetten voor gezond ouder worden}

Gezonde sociale omgevingen kunnen helpen om gezond gedrag te stimuleren. Een voorbeeld hiervan vonden wij in de Freewheel club in Ulft. Daar komt al 6 jaar elke ochtend van 9 tot Io uur een groep van 74 ouderen bijeen om te sporten onder leiding van een oudere vrijwilliger die het leuk vindt om een training te geven. $\mathrm{Na}$ afloop is er de mogelijkheid om samen koffie en thee te drinken.

Deze vorm van gezondheidsbevordering wordt peer coaching genoemd en is vergelijkbaar met bekende initiatieven als Weight Watchers en de Anonieme Alcoholisten. Mensen helpen elkaar om een gemeenschappelijk doel te bereiken. Peer coaching is dankzij het gebruik van non-professionals, meestal vrijwilligers, een goedkope oplossing die veel mensen kan bereiken. Anonieme Alcoholisten levert wereldwijd aan meer dan twee miljoen mensen in I 50 landen gezondheidsvoordeel op.

Wij onderzochten de motivaties van de deelnemers om lid te worden van de Freewheel club in Ulft. Hierop antwoorden de meeste mensen niet: "om een hartinfarct of suikerziekte te voorkomen” - zij antwoorden: "omdat het gezellig is". Het is leuk om samen gezellig buiten te zijn en thee te drinken. Op de tweede plaats kwam dan pas een betere conditie of gezondheid als motivatie om mee te doen. Zonder dat ze het zich bewust waren, zorgde de sociale omgeving ervoor dat ze meer bewogen en zich fysiek fitter voelden (Van de Vijver, Wielens, Slaets, \& Van Bodegom, 2016). 
Niet alleen tijdens het sporten ontmoeten leden van de Freewheel club elkaar. Sommige leden raken bevriend en spreken ook af buiten de sportsessies. Met name voor mensen die al met pensioen zijn, zorgt een dergelijke dynamische groep voor een nieuwe aanwas van contacten. De groep in Ulft begon als initiatief om ouderen meer te laten bewegen, maar blijkt ook een goed middel om sociale contacten op te doen. Peer coaching is op die manier een goedkope en effectieve oplossing om grote groepen ouderen gezond en gelukkig oud te laten worden.

Onze genen maken ons tot wie we zijn ze zijn gedurende duizenden jaren geëvolueerd in een omgeving van schaarste en samenwerken. De mens is daardoor van nature lui, hongerig, maar ook sociaal. Dat laatste kan ingezet worden om de eerste twee eigenschappen geen probleem te laten zijn in onze omgeving van overvloed. Het initiatief in Ulft is redelijk uniek in Nederland. De vraag of dit op grote schaal kan worden ingezet, gaan wij onderzoeken in Leiden, waar wij de eerste $\mathrm{Vi-}$ tality Club gaan oprichten, en naar wij hopen niet de laatste. In Cuba is te zien dat het mogelijk is om dit op grote schaal uit te rollen. Daar zijn meer dan I 5.000 Circulos de Abuelos, ouderenkringen, met in totaal 780.000 ouderen, die iedere ochtend met elkaar sporten, dansen en koffie drinken en op deze wijze gezond en gelukkig oud worden. Onze ambitie is om te onderzoeken hoe wij in Nederland ook een dergelijke gemeenschap - sociale omgeving - kunnen creëren.

\section{Literatuur}

Christakis, N. A., \& Fowler, J. H. (2007). The spread of obesity in a large social network over 32 years. New England Journal of Medicine, $357(4), 370-379$.
Hollands, G. J., Shemilt, I., Marteau, T. M., Jebb, S. A., Lewis, H. B., Wei, Y., ... Ogilvie, D. (20I5). Portion, package or tableware size for changing selection and consumption of food, alcohol and tobacco. Cochrane Database Syst Rev(9), CdoII045. doi:Io.I002/I4651858.CDoII045.pub2 Holt-Lunstad, J., Smith, T. B., Baker, M., Harris, T., \& Stephenson, D. (2015). Loneliness and social isolation as risk factors for mortality a meta-analytic review. Perspectives on Psychological Science, IO(2), 227-237.

Koopmans, T. A., Geleijnse, J. M., Zitman, F. G., \& Giltay, E. J. (2010). Effects of happiness on all-cause mortality during is years of followup: The Arnhem Elderly Study. Journal of Happiness Studies, II(I), II3-I24.

Van Bodegom, D., \& Westendorp, R. G. J. (2015). Oud worden in de Praktijk: Atlas contact.

Van de Vijver, P. L., Wielens, H., Slaets, J. P. J., \& Van Bodegom, D. (2016). The FreeWheel club: a proof-of-principle of peer coaching for daily physical activity by older people. submitted.

\section{Over de auteurs}

Paul van de Vijver is student geneeskunde. Hij is aangesteld als promovendus bij de Leyden Academy on Vitality and Ageing, waar hij onderzoek doet naar de rol van peer coaching bij gezond oud worden. David van Bodegom is verouderingswetenschapper bij het kennisinstituut Leyden Academy on Vitality and Ageing. Hij is opgeleid tot arts en ervan overtuigd dat niet de spreekkamer maar de publieke ruimte de sleutel is tot gezonde veroudering. 